\title{
Specialized Center Grant
}

National Cancer Institute

\section{Source}

National Cancer Institute. Specialized Center Grant. NCI Thesaurus. Code C20019.

Support all aspects of R\&D from basic to clinical and may involve ancillary support activities such as patient care. They differ from program project grants in that they are usually developed in response to an institute initiative and subsequently receive continuous attention from its staff. Centers also may serve as regional or national resources for special research. 